\title{
DEVELOPMENT HOUSE INCUBATOR UNIT OPERATED WITH RENEWABLE ENERGY
}

\author{
El-Sebaee, I. M. *
}

\begin{abstract}
A new system of solar house incubator design is recommended to be used for hatch eggs using solar energy as step for maximizing renewable source of energy instead of traditional power. The indoor experiments were conducted under two methods to keep the incubator temperature at the optimum level. The first, using solar collector and heater works by solar cell. The second is the heater works by solar cell only. The DC motor used to move mat and automatically change eggs position. This system controlled by using the electronic circuits and mechanical thermocouple to supply a requirement eggs temperature $\left(39{ }^{\circ} \mathrm{C}\right)$. The entire element will be controlled using programmable integrated circuit. The programmable integrated circuit is a type of microcontroller that can process a data from sensor and will execute the control element to change the condition in the incubator. The experimental periods from $7^{\text {th }}$ to $28^{\text {th }}$ of February (first period) and from $1^{\text {st }}$ to $20^{\text {th }}$ of June (second period) 2017 were recorded and evaluation at Tractor Test Station. The total power with solar collector decreases by $26.8 \%$ and $37.5 \%$ compared to the total power when using the tradional method at the first and second period respectively.
\end{abstract}

Key word: house incubator; renewable energy; Solar Energy.

\section{INTRODUCTION}

I ncubator is the fashionable technology to hatch eggs without involving its brooding parent. The observable difference between natural and artificial incubation is the process where natural parent provides warmth by contact rather than surrounding the egg with warm air. There are many important basics in the incubation system which is including the constituent of air, humidity and the temperature during the incubation process. All of these factors are very important for the incubation process.

\footnotetext{
* Agric. Eng. Res. Inst. (AEnRI), Giza, Egypt.
} 
There are many types of the incubator designed manual, semi-automatic or automatic entirely. Still air incubator with no exhaust fan is unable to circulate the air. Therefore, forced air model is widely used because it has an exhaust fan to circulate the hot air to maintain the level of heat, moisture and oxygen content in the incubator(Nakage et al. 2003). Forced air model is equipped with an automatic rotator which rotates the eggs at least twice per day. Humidifiers are of several types, some are actuated by wet bulb systems while others are designed to maintain humidity by a simple water reservoir surface area system (Benjamin and Oye, 2012).

Incubation is the process which birds hatch their eggs and development of an embryo within the egg. The very important factor in incubation process is the constant temperature per a specific period. Furthermore, humidity is the very important to provide enough moisture during the incubation process to keep away from dry atmosphere that can make hatching becomes more difficult. As incubation proceeds, an egg will normally become lighter, and the air space within the egg will become larger, owing to the evaporation from the egg (Abu and Ramli, 2008).Lourens et al. (2005) indicated that there are two types of incubator in the market which are forced air incubator and still air incubator. Forced air incubator has an exhaust fan to circulate the air inside the incubator while the still air incubator is using the convection air exchange in and out where the hot air will come out and cold air will enter through the ventilation holes. The recommended temperature for incubation process is also different for both types of these machines. $\mathrm{He}$ added that humidity is the other major important parameter, during the embryos bone development stage. During incubation (embryonic development) moisture is lost from the eggs through the tiny holes on the shell; this increases the air cell size, which after 19 days of incubation occupies about one third of the eggs.

Turning mechanism ensures the embryo is fully developed and in position to hatch when the eggs are positioned in the incubator. Eggs are placed vertically with the air cell at the top of the eggs in common practice. Any eggs that are positioned on their side should be turned 
along their long axis. This indicated the eggs are set to $45^{\circ}$ angle, after a $90^{\circ}$ turn whilst they face $45^{\circ}$ in the other direction (Jeffery et al. 2008).

Ramli et al. (2015) design and develop a force air system of eggs incubator to incubate various types of eggs through a conveyor rotating system. This incubator was equipped with temperature and humidity sensors to measure and control the condition in the incubator. While, Radhakrishnan et al. (2014) added that this system has a temperature sensor which is able to monitor the temperature inside and outside the incubator and this data is sent to a microcontroller. The microcontroller, with the help of relays controls an incandescent lamp and an air circulating fan to maintain the egg temperature from 37 to $38.5^{\circ} \mathrm{C}$. In addition, an LCD display is used to display the temperature inside and outside the incubator.

This research aimed to develop the new house incubator by controlling the temperature and to keep humidity at the optimum limit automatically. And to decrease the total power consumption using solar house incubator to increase the farmer income and produce product with a small amount of eggs that they need in their life.

\section{MATERIALS AND METHODS}

Under indoor experiments, two methods used to keep the incubator temperature consent per the optimum level were identified:-

- Using the solar collector all day, if the temperature at the solar collector is more than $39^{\circ} \mathrm{C}$ and if the temperature became less than $39{ }^{\circ} \mathrm{C}$, the electric heater (lamp) works by the solar cell is used to give the suitable temperature to the eggs. This operation is controlled by the electronic circuits.

- Using the solar cell only all day, if the temperature became less than $39^{\circ} \mathrm{C}$, the electric heater (lamp) works by the solar cell is used to give the suitable temperature to the eggs. This operation is controlled by the electronic circuits.

To identified above condition, the system as shown in Fig. (1) Consists of three parts that have to controlled humidity, temperature and movement of the eggs. The electric heater (lamp) works by solar cell and 
the solar collector were used to give the suitable temperature. The percentage of the humidity in the incubator needs to balance by control the fan and water through in the incubator. Eggs must change their location 6 times per day by using the DC motor. The house incubator will plug up with the temperature sensor that can measure the condition of the incubator and without human intercession change to the appropriate state for the eggs.

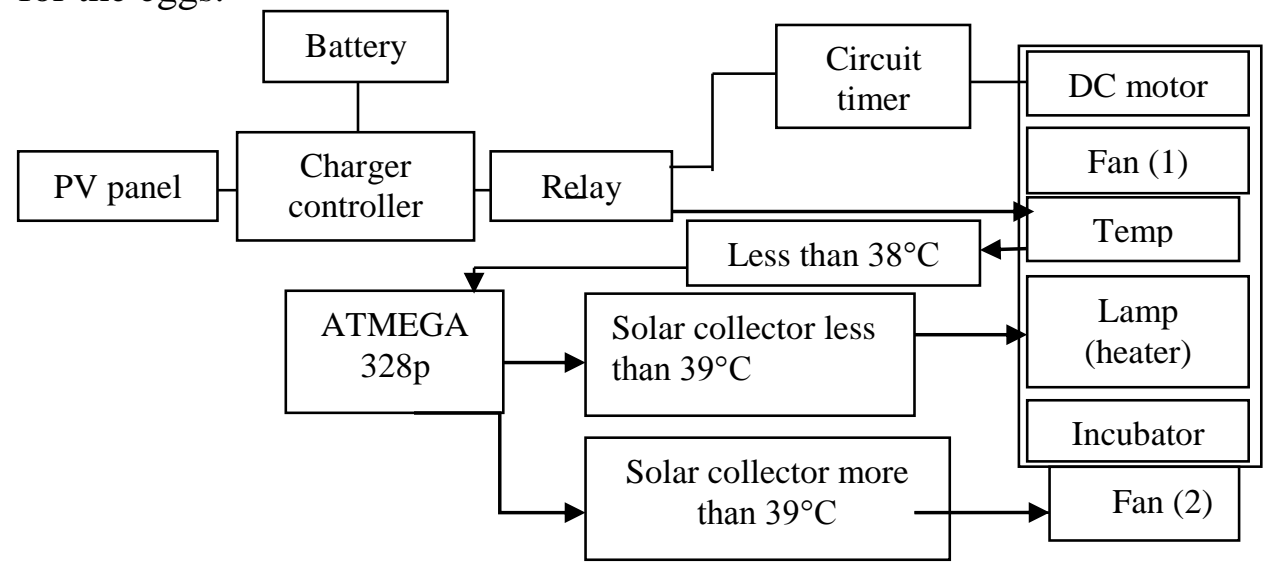

Fig (1): Block diagram of the incubator solar energy

\section{Working and Circuit diagram for the solar energy incubator.}

The microcontroller (ATmega 328p) as shown in Fig (2) is able to automatically maintain the environment which is optimum for embryo growth. The system has a temperature sensor (LM 35) to monitor the temperature inside and outside the solar collector which it is sent to a microcontroller. The microcontroller and relays controls a lamp and an air circulating fan to maintain the eggs at the optimum temperature " 37 to $39^{\circ} \mathrm{C}$ ". In addition, there is a circuit timer used to control a gear motor for rotating the eggs every four hours.

The LM 35 temperature sensor is placed at the middle of the solar collector. The microcontroller constantly check the temperature returned from the LM35 temperature sensor. If the temperature value at the solar collector become more than $39^{\circ} \mathrm{C}$ the fan (2) is working to suction the hot air from the solar collector to increase the temperature at the incubator to the optimum degree, but if the temperature in the solar collector is less than $39^{\circ} \mathrm{C}$ the electric heater (lamp) with $12 \mathrm{~V}$ works to 
increase the temperature to the optimum degree. The circulating fan (1) $(12 \mathrm{~V})$ works continuously to distribute the air at all over of the incubator. This process continues till the temperature reaches to the optimum degree. Once this range is exceeded the relay is turned off and the electric heater (lamp) turned off, till the temperature goes below the lower limit again, the process will start again to reach to the optimum temperature. All electric parts of the incubator works by the solar cell.

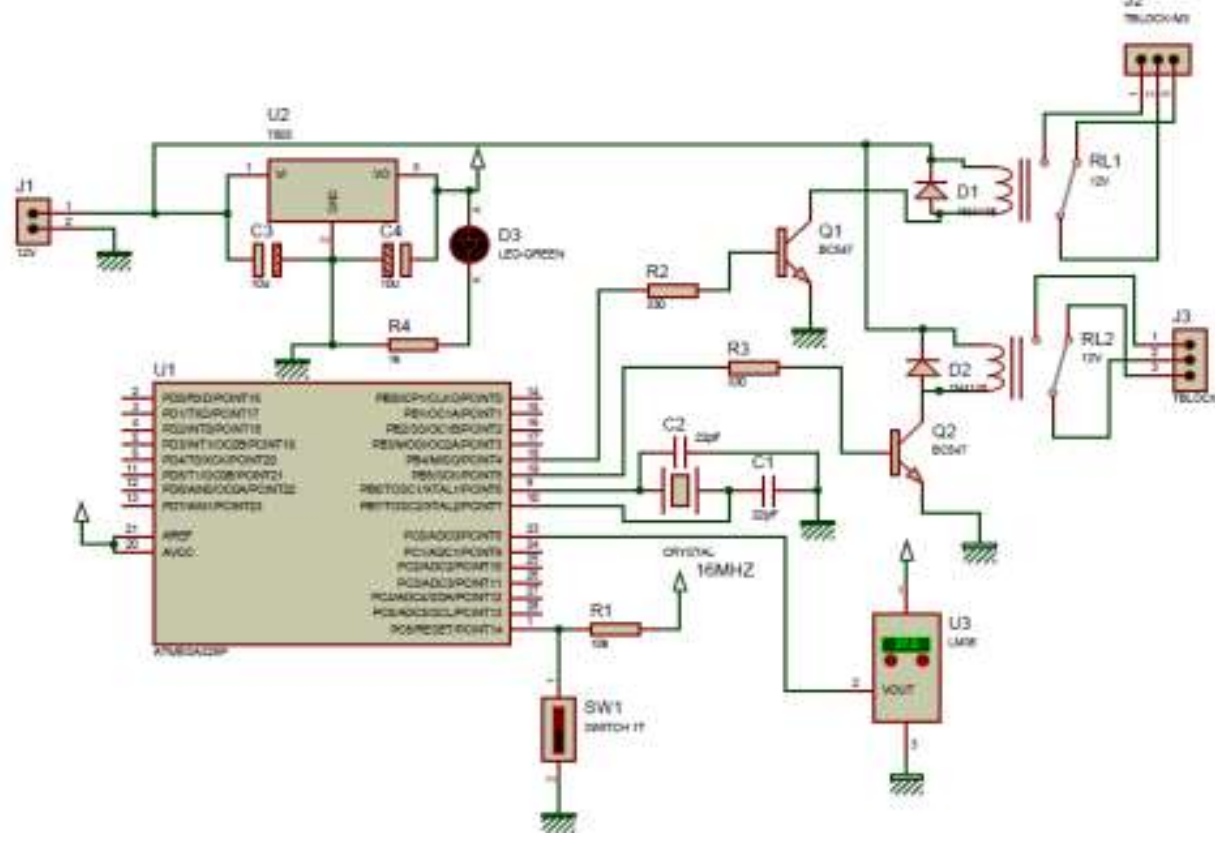

Fig. (2): Circuit diagram connected with microcontroller

\section{Solar energy incubator design}

\section{Incubator casing}

The incubator system involves lots of concern in terms of the temperature, humidity and movement in order to care the health of embryo in the egg. The eggs in the incubator need to change their position slowly and smoothly every 4 hours, since jostling would disturb the development of the chicks. By using the DC motor, timer circuit to change its position every four hours. Humidity of the incubator was controlled by water container to give some fresh air flow and fan controller to make the suitable humidity in incubator and solar collector to work at the time, when its temperature more than 39 ${ }^{\circ} \mathrm{C}$. an electric heater (lamp) $(40 \mathrm{~W})$ was placed inside the incubator to supply heat to the eggs 
As shown in Fig (3), the construction of the incubator will begin with the built the casing of the incubator. A good quality material was used such as hardwood and foam. This incubator can fill up to 20 eggs.

The incubator dimension:

Side length $=39 \mathrm{~cm} \quad$ Side width $=48.4 \mathrm{~cm} \quad$ Height $=48.4 \mathrm{~cm}$.
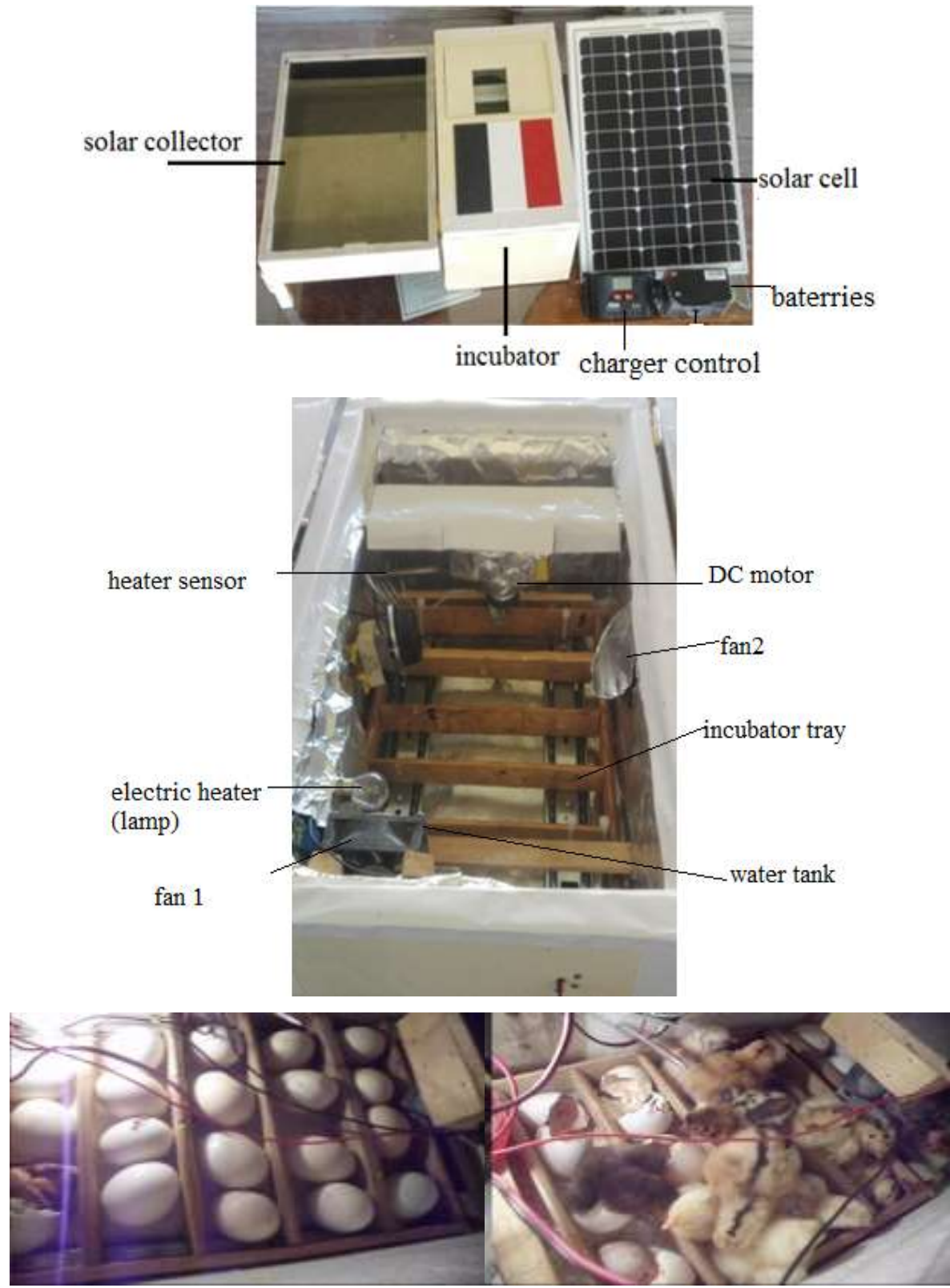

Fig (3): The solar energy house incubator components 


\section{Data logger}

The Campel scientific data logger as shown in Fig (4) used to collecting data of the solar radiation, air temperature, incubator temperature, incubator air humidity and solar collector temperature. The sensors are connected to Campel scientific data logger (CR 10X) that have been programmed to store a measure of all sensors at one-minute intervals. The averages of values have been measured every one hour.

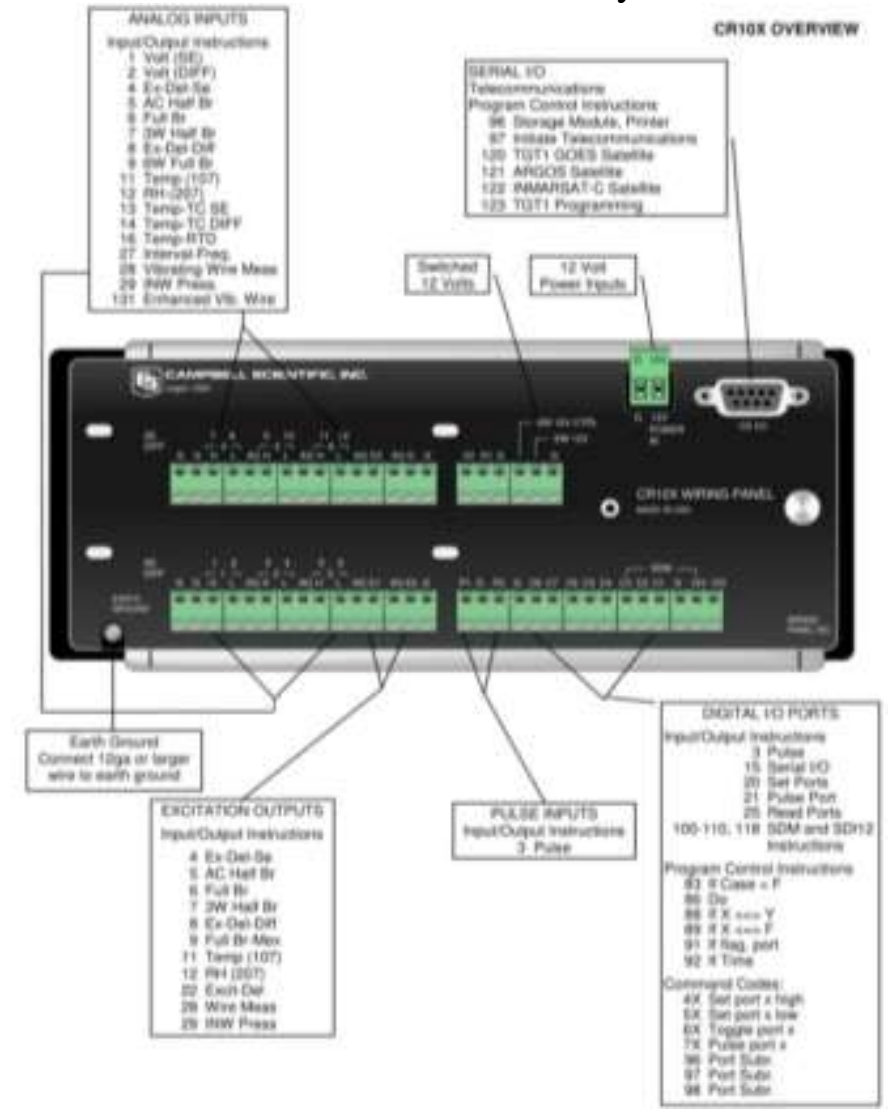

Fig (4): Campel scientific data logger CR10X.

\section{DC power supply}

DC power supply (GPR-3510HD) as shown in Fig (5) with a maximum voltage and amps of $35 \mathrm{~V}$ and $10 \mathrm{~A}$, input rating $570 \mathrm{~W}$ at $220 \mathrm{~V}$, the weight is $18.5 \mathrm{Kg}$ and its dimensions are (225 X145 X420 mm). The DC power supply is directly connected to the components of the incubator and supplies the direct current (D.C.) to measure the maximum ampere and volt. The maximum ampere and volt measured for the incubator and the results of the data shown in Table (1). 


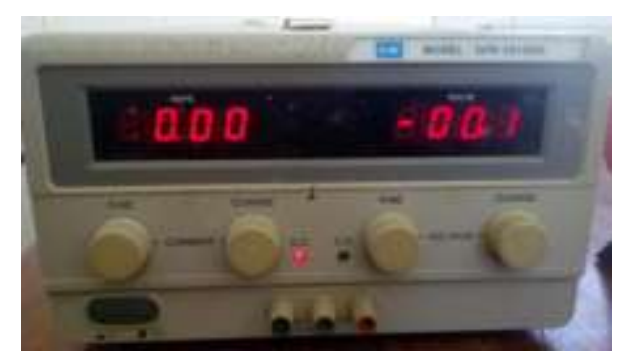

Fig (5): DC power supply (GPR-3510HD).

Table (1): Maximum Ampere and Volt for the house incubator

\begin{tabular}{|c|c|c|c|c|c|c|}
\hline $\begin{array}{c}\text { maximum } \\
\text { ampere }\end{array}$ & $\begin{array}{c}\text { maximum } \\
\text { volt ( v) }\end{array}$ & $\begin{array}{c}\text { Power, W } \\
\text { (lamp) }\end{array}$ & $\begin{array}{c}\text { Power, W } \\
\text { (motor) }\end{array}$ & $\begin{array}{c}\text { Power, W } \\
\text { (fan1) }\end{array}$ & $\begin{array}{c}\text { Power, W } \\
\text { (fan2) }\end{array}$ & $\begin{array}{c}\text { Maximum } \\
\text { total power, W }\end{array}$ \\
\hline 3.54 & 12 & 40 & 0.84 & 1.56 & 1.56 & 42.4 \\
\hline
\end{tabular}

The Maximum total power for $[($ lamp $)+($ motor $)+($ fan 1$)]$ used when the solar collector wasn't used.

The solar energy components that used to operate the solar energy incubator as shown in Fig (6)was constructed to operate the incubator at the maximum power case .Most of the used materials are already available in the local market in standard form. These include:

- 2 Battery(12V-50 Amps),

- 3solar panel, 60 watts and 12 volts,

- Charger control.

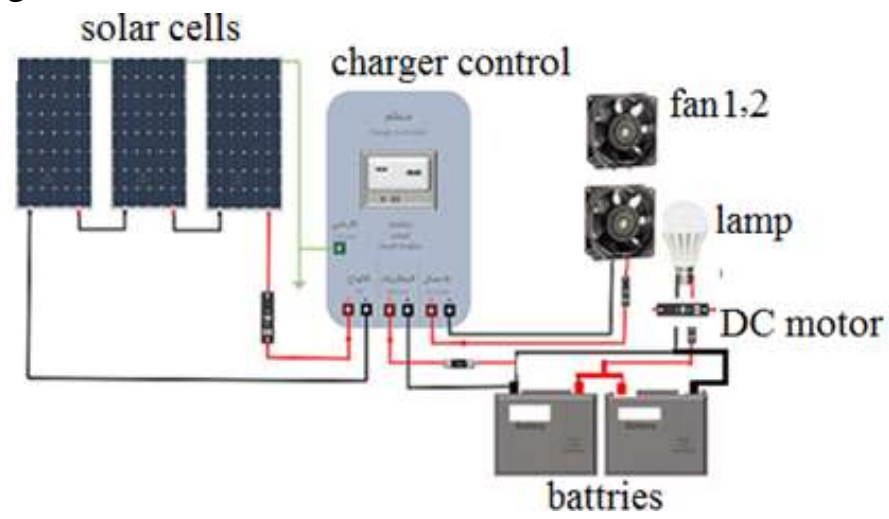

Fig (6): The Solar Energy Components.

\section{Design Calculations}

The incubator design calculations were based on the conditions required for the machine to work effectively. Some of the conditions were the temperature of the incubator which was to be maintained, relative 
humidity and the turning mechanism. It was also based on design considerations such as materials selection, standards and required parameters.

\subsection{Capacity of the Incubator Egg Tray}

Regarding to the principle of mathematical lows, the eggs tray volume can be estimated as volume of one egg multiply in number of eggs from the following equation;

$$
\mathrm{V}_{\mathrm{t}}=\frac{\pi D^{2} \mathrm{Hn}}{4}
$$

Where,

$$
\begin{aligned}
& V_{t}=\text { volume of the egg tray }\left(\mathrm{m}^{3}\right) \quad \mathrm{D}=\text { minor diameter }(40 \mathrm{~mm}) \\
& \mathrm{H}=\text { height of the egg tray or major diameter }(58 \mathrm{~mm}) \\
& \mathrm{n}=\text { number of eggs on an egg tray }=20 \quad \text { Border end }=21 \mathrm{~mm}
\end{aligned}
$$

Then,

$$
\mathrm{V}_{\mathrm{t}}=0.001457 \mathrm{~m}^{3}
$$

The egg tray was rectangular in shape with a height of $58 \mathrm{~mm}$.

Let the length of the tray be 1.5 width of egg tray and the distance between two eggs is $3 \mathrm{~mm}$;

$$
\mathrm{L}=1.5 \times \mathrm{B}
$$

Where,

$\mathrm{L}=$ length of the egg tray $(\mathrm{m}) \quad \mathrm{N}=$ number of eggs in row $=4$

$\mathrm{B}=$ width of the egg tray $(\mathrm{m})$

$B=(D+0.003) * N=0.172 m$

So,

$\mathrm{L}=1.5 \times \mathrm{B}=0.258 \mathrm{~m}$

The dimension of the tray was $0.258 \times 0.172 \times 0.058 \mathrm{~m}$

\subsection{Volume of Air in the incubator}

The dimension lengths of the incubator are $42 \times 25 \times 15 \mathrm{~cm}$

Thickness of foam $=40 \mathrm{~mm}$

$$
V_{a}=l \times w \times b
$$

Where,

$l=$ length of the incubator $=0.42 \mathrm{~m}$

$w=$ width of the incubator $=0.25 \mathrm{~m}$

$b=$ height of the incubator $=0.15 \mathrm{~m}$

$V_{a}=$ volume of the incubator cabinet $\left(\mathrm{m}^{3}\right)$

$V_{a}=0.016 \mathrm{~m}^{3}$

The volume of air in the incubator $=0.016 \mathrm{~m}^{3}$ 


\subsection{Determination of the Mass of Air $\left(M_{a}\right)$}

$\rho_{a}=\frac{M_{a}}{V_{a}}$

Where $\rho_{\mathrm{a}}=$ density of air $=1.23 \mathrm{~kg} / \mathrm{m}^{3}$ (Rajput, 1998)

$$
\begin{gathered}
\mathrm{M}_{\mathrm{a}}=\text { mass of air }(\mathrm{kg}) \\
M_{a}=\rho_{a} \times V_{a} \\
M_{a}=0.02 \mathrm{~kg}
\end{gathered}
$$

The required mass of air was $0.02 \mathrm{~kg}$

\section{Determination of the Incubator power}

Incubator power without solar collector $=($ heater time $*$ heater power $)$

$+\left(\right.$ fan $_{1}$ time $*$ fan $_{1}$ power $)+($ motor time $*$ motor power $)$

Incubator power with solar collector $=($ heater time $*$ heater power $)+$ $\left(\right.$ fan $_{1}$ time $*$ fan $_{1}$ power $)+($ motor time $*$ motor power $)+\left(\mathrm{fan}_{2}\right.$ time $*$ fan $_{2}$ power)

Where: $\operatorname{fan}_{1}=$ incubator fan $\operatorname{fan}_{2}=$ solar collector fan

\section{Energy Gained by the Solar Collector}

The energy gained by the solar collector can be expressed by the following equation .

$$
Q_{u}=\alpha \tau I_{\delta} A_{c}-U_{L} A_{c}\left(T_{c}-T_{a}\right) \text { Bolaji, (2008) }
$$

Where: $\boldsymbol{A} \boldsymbol{c}=$ area of transparent cover $\left(\mathrm{m}^{2}\right)$

$\boldsymbol{I} \boldsymbol{\delta}=$ total incident radiation on the collector surface $\left(\mathrm{W} / \mathrm{m}^{2}\right)$

$\boldsymbol{U}_{\boldsymbol{L}}=$ overall heat loss for the collector $\left(\mathrm{W} / \mathrm{m}^{2} \mathrm{~K}^{-1}\right)$

$\boldsymbol{\alpha}=$ solar absorptance

$\tau=$ transmittance

$\boldsymbol{T}_{c}=$ collector temperature $(\mathrm{K})$

$\boldsymbol{T} \boldsymbol{a}=$ ambient air temperature (K)

\section{Total heat requirement}

The total heat requirement of the incubator $\left(Q_{T}\right)$ is the summation of the heat energy required to raise the temperature of air $\left(\boldsymbol{Q}_{a}\right)$ and egg $\left(\boldsymbol{Q}_{e}\right)$ from ambient temperature to $38.5^{\circ} \mathrm{C}$; the heat loss through the wall of the structure $\left(\boldsymbol{Q}_{s}\right)$ and the heat loss by ventilation $\left(\boldsymbol{Q}_{v}\right)$.

$$
Q_{T}=Q_{a}+Q_{e}+Q_{s}+Q_{v}
$$

Bolaji, (2008).

The following relations were used to determine the heat requirements, Bolaji, (2008)

$$
Q_{e}=m_{e} C_{e} \Delta T
$$




$$
\begin{gathered}
Q_{a}=m_{a} C_{a} \Delta T \\
Q_{v}=\rho V \Delta T
\end{gathered}
$$

Where,

$$
\begin{aligned}
& \boldsymbol{m}_{\boldsymbol{e}}=\text { eggs mass }(\mathrm{kg}) \quad \boldsymbol{m} \boldsymbol{a}=\text { air mass }(\mathrm{kg}) \\
& \boldsymbol{C}_{\boldsymbol{e}}=\text { specific heat capacity of egg }\left(\mathrm{kJ} / \mathrm{kgK}^{-1}\right) \\
& \boldsymbol{C}_{\boldsymbol{a}}=\text { specific heat capacity of air }\left(\mathrm{kJ} / \mathrm{kgK}^{-1}\right) \\
& \boldsymbol{A} \boldsymbol{T}=\text { temperature difference }(\mathrm{K}) \\
& \boldsymbol{A}=\text { surface area of the incubator walls }\left(\mathrm{m}^{2}\right) \\
& \boldsymbol{\rho}=\text { air density }\left(\mathrm{kg} / \mathrm{m}^{3}\right) \quad \boldsymbol{V}=\text { ventilation rate }\left(\mathrm{m}^{3} / \mathrm{s}\right)
\end{aligned}
$$

\section{Heat Loss at Opposite Sides of the Incubator}

The heat loss at opposite sides of the incubator could be calculated because of their equal surface areas and also made up of the same material (foam).

$$
\begin{gathered}
\operatorname{Area} A=2 * w * l \\
q=\frac{A * K *\left(T_{2}-T_{1}\right)}{L}
\end{gathered}
$$

Where,

$$
\begin{aligned}
& \boldsymbol{T}_{\mathbf{1}}=\text { incubatortemperature } \\
& \boldsymbol{T}_{2}=\text { ambient temperature }
\end{aligned}
$$

\section{Heat Loss at Bottom Surface of the Incubator}

The top and bottom surfaces of the incubator were equal and opposite made of the same material.

$$
A=2 * l * b
$$

Then,

$$
q=\frac{A * K *\left(T_{2}-T_{1}\right)}{L}
$$

Heat Loss at the Front and Back of the Incubator

$$
\boldsymbol{A}=\mathbf{2} * \boldsymbol{w} * \boldsymbol{b}
$$

Then,

$$
q=\frac{A * K *\left(T_{2}-T_{1}\right)}{L}
$$

\section{RESULTS AND DISCUSSIONS}

As shown in table (2) the results of the incubator data in $1^{\text {st }}$ June 2017 was regulated with average temperature of $37.7^{\circ} \mathrm{C}$, the average humidity 
of $55 \%$, the minimum air temperature of $19.2^{\circ} \mathrm{C}$, the maximum air temperature of $30^{\circ} \mathrm{C}$ and the solar collector temperature more than $39^{\circ} \mathrm{C}$ nearly for 11 hours. The maximum solar collector temperature was $64^{\circ} \mathrm{C}$ at $12 \mathrm{pm}$. The incubator designed to change the eggs position slowly and smoothly every 4 hours per one minute.

Table (2): The incubator data in the first day

\begin{tabular}{|c|c|c|c|c|c|c|}
\hline $\begin{array}{l}\text { Time } \\
\text { (hr.) }\end{array}$ & $\begin{array}{c}\text { Average Incubator } \\
\text { Temperature } \\
\left({ }^{\circ} \mathrm{C}\right)\end{array}$ & $\begin{array}{c}\text { Humidity } \\
(\%)\end{array}$ & $\begin{array}{l}\text { Turning } \\
\text { mat time } \\
\text { (min) }\end{array}$ & $\begin{array}{c}\text { Air } \\
\text { temperature } \\
\left({ }^{\circ} \mathrm{C}\right)\end{array}$ & $\begin{array}{l}\text { Solar collector } \\
\text { temperature } \\
\left({ }^{\circ} \mathrm{C}\right)\end{array}$ & $\begin{array}{c}\text { Solar } \\
\text { radiation } \\
\left(\mathrm{W} / \mathrm{m}^{2}{ }^{\circ} \mathrm{C}\right)\end{array}$ \\
\hline 1 & 37.6 & 59 & & 20.4 & 20.4 & 0 \\
\hline 2 & 38 & 58 & & 20.1 & 20.1 & 0 \\
\hline 3 & 37.4 & 60 & & 19.8 & 19.8 & 0 \\
\hline 4 & 37.5 & 62 & 1 & 19.3 & 19.3 & $\mathbf{0}$ \\
\hline 5 & 37.9 & 63 & & 19.2 & 19.2 & $\mathbf{0}$ \\
\hline 6 & 37.6 & 61 & & 19.9 & 19.9 & $\mathbf{0}$ \\
\hline 7 & 37.4 & 59 & & 22.2 & 40.1 & 216.6 \\
\hline 8 & 37.9 & 57 & 1 & 24.2 & 48.6 & 410.9 \\
\hline 9 & 37.6 & 51 & & 26.4 & 56.7 & 616.4 \\
\hline 10 & 37.5 & 49 & & 27.9 & 57 & 782.5 \\
\hline 11 & 37.6 & 50 & & 30 & 62.7 & 899.5 \\
\hline 12 & 37.3 & 52 & 1 & 29.4 & 64 & 941.5 \\
\hline 13 & 37.7 & 53 & & 28 & 63.1 & 948.5 \\
\hline 14 & 38 & 54 & & 26.9 & 62.3 & 885 \\
\hline 15 & 38.1 & 52 & & 25.9 & 59.7 & 747.3 \\
\hline 16 & 37.6 & 49 & 1 & 25.5 & 57.1 & 601.9 \\
\hline 17 & 37.6 & 53 & & 24.8 & 50 & 405.4 \\
\hline 18 & 38.2 & 57 & & 24.6 & 40.1 & 180 \\
\hline 19 & 37.7 & 58 & & 23.2 & 23.2 & $\mathbf{0}$ \\
\hline 20 & 37.5 & 59 & 1 & 21.7 & 21.7 & $\mathbf{0}$ \\
\hline 21 & 37.7 & 54 & & 21.2 & 212 & $\mathbf{0}$ \\
\hline 22 & 37 & 57 & & 20.8 & 20.8 & $\mathbf{0}$ \\
\hline 23 & 38 & 56 & & 20.4 & 20.4 & $\mathbf{0}$ \\
\hline 24 & 37.5 & 59 & 1 & 20.1 & 20.1 & 0 \\
\hline
\end{tabular}

As shown in Fig (7),the results of the incubator data in the experimental period from $1^{\text {st }}$ June to $20^{\text {th }}$ June 2017 were determine and the average temperature was $37.66{ }^{\circ} \mathrm{C}$, the average humidity was $56.3 \%$, the minimum air temperature was $19.2^{\circ} \mathrm{C}$, the maximum air temperature was $35^{\circ} \mathrm{C}$, the total power with solar collector was $6.4 \mathrm{kw}$ while the total power with traditional method was $10.23 \mathrm{kw}$, the total power with solar collector decreases by $37.5 \%$ compared to the total power when using the tradional method and The solar collector temperature was more than 39 ${ }^{\circ} \mathrm{C}$ nearly for 11 hours every day . 


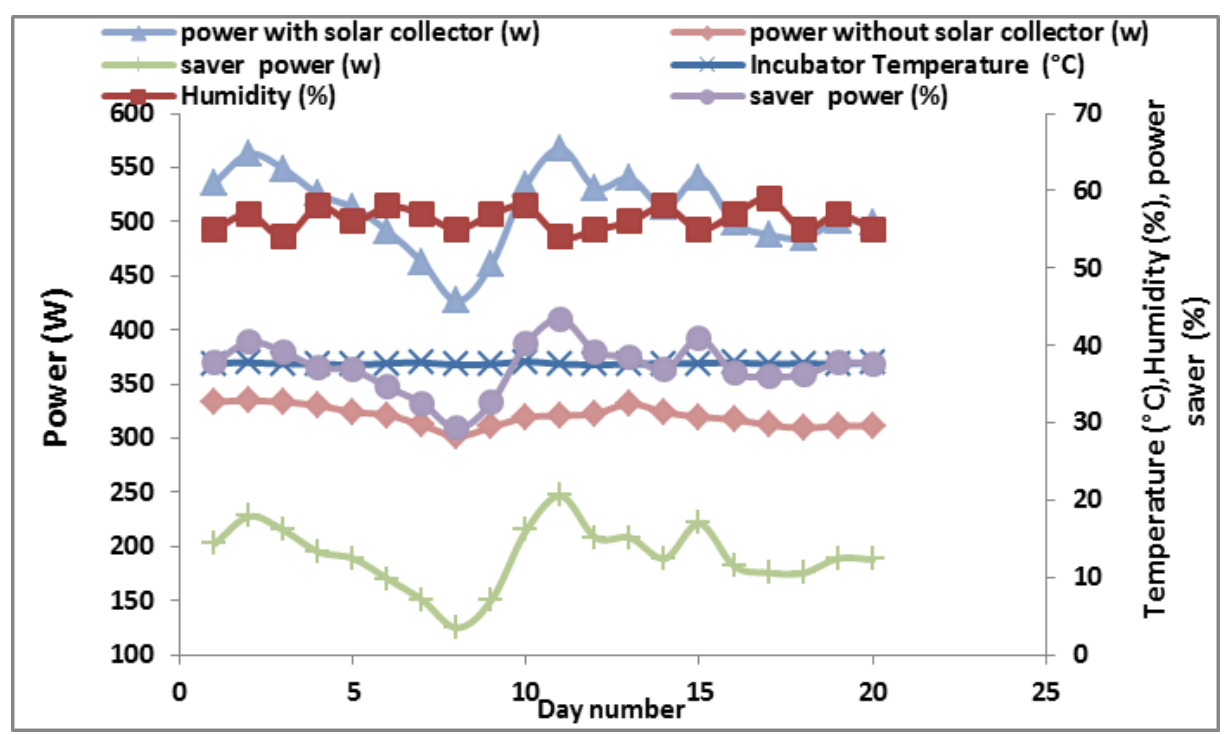

Fig (7): The incubator data in the experimental period from $1^{\text {st }}$ June to $20^{\text {th }}$ June 2017

As shown in fig (8), the results of the incubator data in the experimental period from $7^{\text {th }}$ to $28^{\text {th }}$ February 2017 were determine and the average temperature was $37.7{ }^{\circ} \mathrm{C}$, the average humidity was $55.8 \%$, the minimum air temperature was $10^{\circ} \mathrm{C}$.

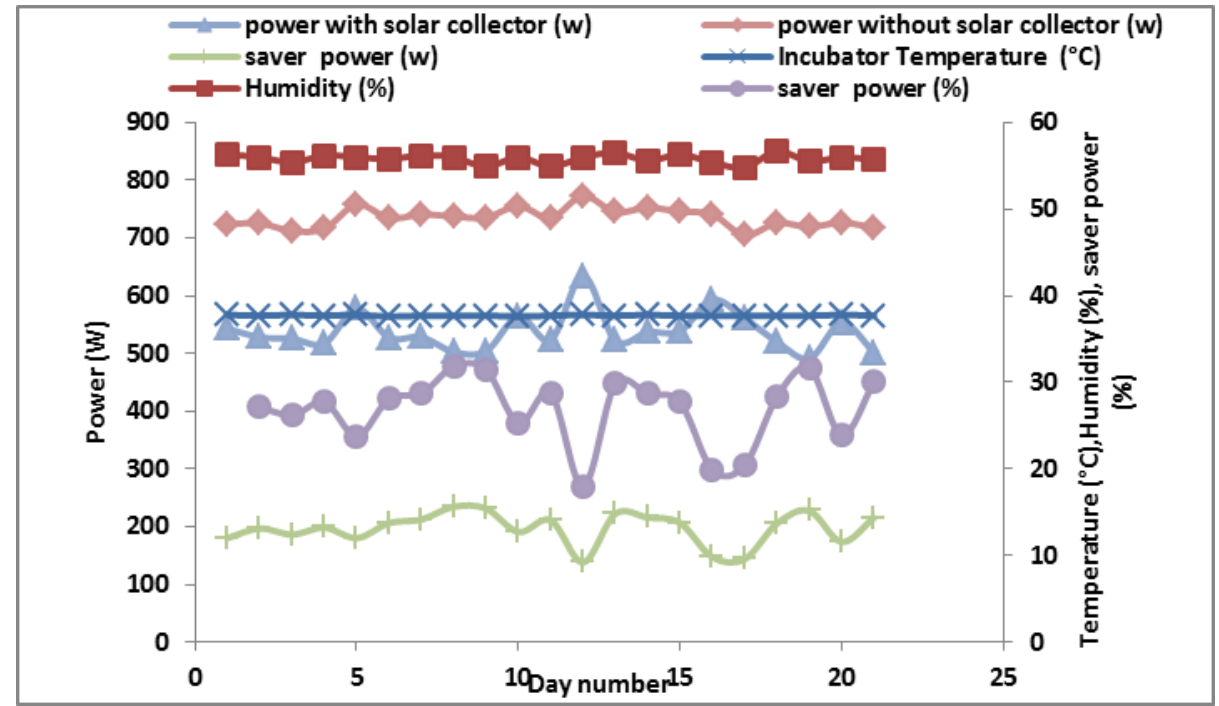

Fig (8): The incubator data in the experimental period from $7^{\text {th }}$ to $28^{\text {th }}$ February 2017 
The maximum air temperature was $28{ }^{\circ} \mathrm{C}$, the total power with solar collector was $11.3 \mathrm{kw}$ while the total power with traditional method was $15.5 \mathrm{kw}$, the total power with solar collector decreases by $26.8 \%$ compared to the total power when using the tradional method and The solar collector temperature was more than $38^{\circ} \mathrm{C}$ nearly from 5 to 9 hours every day at this period.

\section{CONCLUSION}

A new system of solar house incubator design is handy, inexpensive and easy to maintain. The solar energy should be used as heat source because of the untimely failure of electricity to enhance the efficiency of the system. There are two methods used to keep the temperature at the optimum temperature by using the solar collector all day when the temperature at the solar collector is more than $39{ }^{\circ} \mathrm{C}$, but when the temperature at the solar collector less than $39{ }^{\circ} \mathrm{C}$ the heater is used to give the suitable temperature to the egg. This operation is controlled by the electronic circuits and mechanical thermocouple. The lamp is used to heat the egg and the DC motor is very useful to rotate mat at the bottom side and automatically change the position of egg. Evaluation and tests were carried out on tractor test station. The experimental periods were from $7^{\text {th }}$ to $28^{\text {th }}$ of February (first period) and from $1^{\text {st }}$ to $20^{\text {th }}$ of June (second period) 2017.The first period from $7^{\text {th }}$ to $28^{\text {th }}$ February 2017 were determine and the average temperature was $37.7^{\circ} \mathrm{C}$, the average humidity was $55.8 \%$, the minimum air temperature was $10{ }^{\circ} \mathrm{C}$, the maximum air temperature was $28^{\circ} \mathrm{C}$, the total power with solar collector was $11.3 \mathrm{kw}$ while the total power with traditional method was $15.5 \mathrm{kw}$, the total power with solar collector decreases by $26.8 \%$ compared to the total power when using the tradional method and The solar collector temperature was more than $38^{\circ} \mathrm{C}$ nearly from 5 to 9 hours every day at this period. The second period from $1^{\text {st }}$ June to $20^{\text {th }}$ June 2017 were determine and the average temperature was $37.66{ }^{\circ} \mathrm{C}$, the average humidity was $56.3 \%$, the minimum air temperature was $19.2^{\circ} \mathrm{C}$, the maximum air temperature was $35^{\circ} \mathrm{C}$, the total power with solar collector was $6.4 \mathrm{kw}$ while the total power with traditional method was $10.23 \mathrm{kw}$, 
the total power with solar collector decreases by $37.5 \%$ compared to the total power when using the tradional method and The solar collector temperature was more than $39{ }^{\circ} \mathrm{C}$ nearly for 11 hours every day .

\section{REFERENCES}

Abu. M. A. and M. B. Ramli (2008)"Development of smart egg incubator system for various types of egg (SEIS)," Universiti Malaysia Pahang, Pahang.

Benjamin. N. and N. Oye(2012)"Modification of the design of poultry incubator," International Journal of Application or Innovation in Engineering \& Management (IJAIEM), vol. 1, no. 4, pp. 90-102.

Bolaji B.O. ( 2008)“'Design and Performance Evaluation of a Solar Poultry Egg Incubator", Thammasat Int. J. Sc. Tech., Vol. 13, No. 1, Abeokuta, Nigeria,.

Jeffery J, G. Martin and R. Fanguy (2008) "The incubation of ratite eggs," Texas A \& W University System, Texas.

Lourens A, H. Van den Brand, R. Meijerhof and B. Kemp (2005) "Effect of eggshell temperature during incubation on embryo development, hatchability, and post hatch development," Poultry Sci, vol. 84, no. 6, pp. 914-920.

Nakage E, J. Cardozo, G. Pereira, S. Queiroz and I. Boleli. (2003)"Effect of temperature on incubation period, embryonic mortality, hacth rate, eggs water loss and partridge chick weight," RevistaBrasileira de CiênciaAvícola, vol. 5, no. 2, pp. 131-135.

Radhakrishnan.K, N. Jose, S. G .Sanjay, T. Cherian and K. R. Vishnu (2014)"design and implementation of a fully automated egg incubator" IJAREEIE. Vol. 3, Issue 2, 7666-7672 .

RamliM. B, P. L. Hooi, M. S. Wahab, M. F. M. Zin.(2015) "Egg hatching incubator using conveyor rotation system" Procedia Manufacturing (2). $527-531$. 


\section{الملخص العربي \\ تطويروحدة تفريخ منزلية تعمل بالطاقة المتجددة \\ * داسلام محمد السيد السباعى}

تم تطويروحدة تفريخ منزلية تعمل بالطاقة المتجددة بحيث يمكن استخدامها فى تفريخ جميع

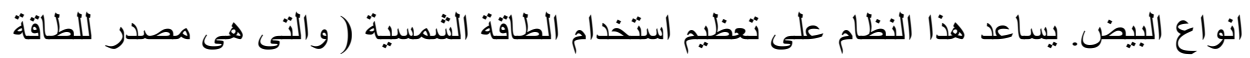
المتجددة) بدلا من الطاقة التقليدية. ولذلك نتوجة الى استخدام الطاقة الشمسية كبديل للطاقة الكهربائية التقليدية وكذلك للوقود فى تشغيل مفرخة تعمل بالطاقة الثمسية حيث يتم استخدام مبدل حرارى لتوفير الطاقة اثناء فترة تواجد الثمس على مدار النهار عندما تكون درجة

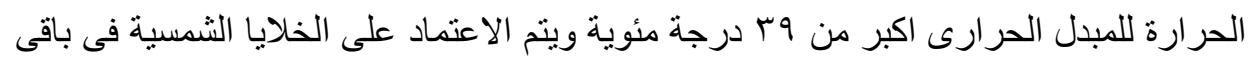

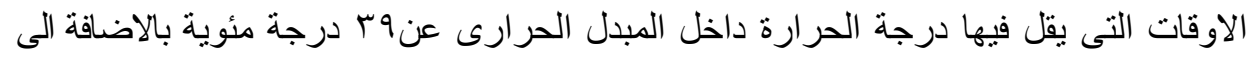
استخدام موتور بسيط يعمل بالطاقة الثمسية وكنلك يعمل على حركة الييض كل (ع) ساعات حتى يكون

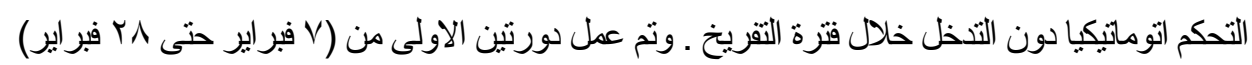

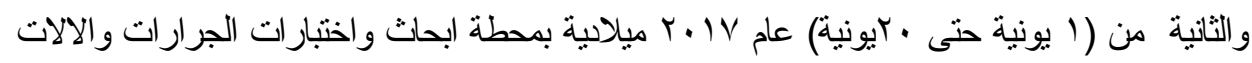

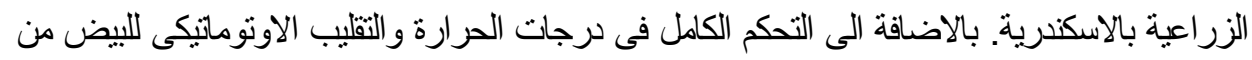
خلال وحدة تحكم الكترونية. ووجد ان المفرخة تعمل بكفاءة مرتفعة خلال الايام التى تزيد فيها بلائ

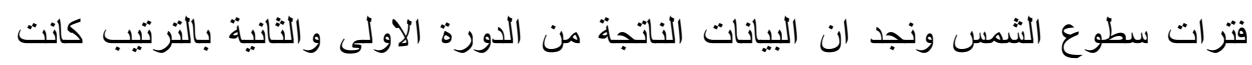
كالاتى متوسط درجة الحرارة داخل المفرخة خلال فترة التفريخ (

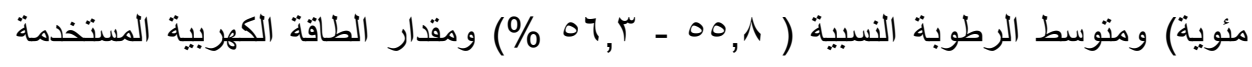

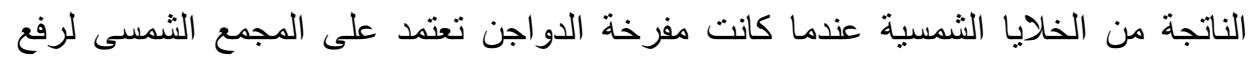

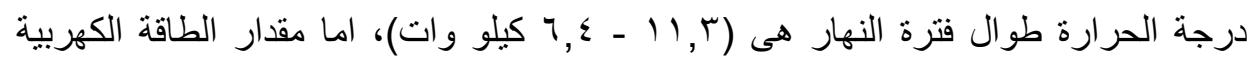

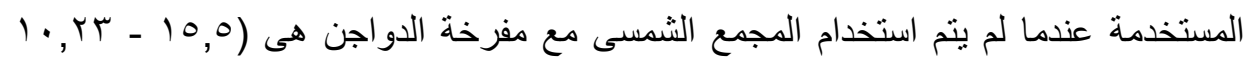

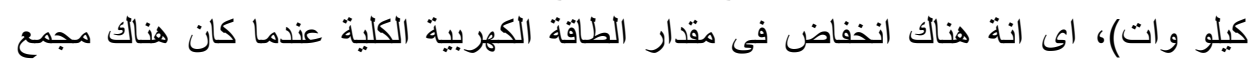

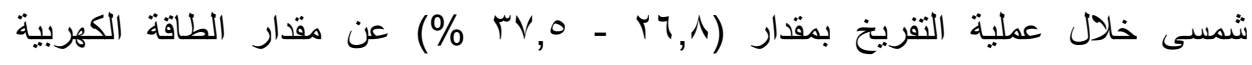
التقليدية.اقصى درجة حرارة كان يصل اليها المجمع الثمسى كان فى منتصف النهار عند الساعة الثانية عشرظهر ا.وكانت نسبة التفريخ ، 9 \% .لذلك يوصى باستخدام المفرخة المطورة فى الايام ذات عدد ساعات سطوع الثمس المرتفعة وذلك حتى يتم تخفيض تكاليف الانتاج قدر المستطاع ويزيد من دخل الفلاح بالاضافة الى استخدامها فى المناطق الصحر اوية و التى تكون بعيدة عن مصدر التيار الكهربى التقليدى.

باحث بمعهد بحوث الهندة الزراعية ـ مركزالبحوث الزراعية - جيزة.

Misr J. Ag. Eng., October 2019 